\title{
WPROWADZENIE.
}

\section{U PODSTAW SYNTEZY WIEDZY. O SZLIFOWANIU NARZĘDZI MYŚLENIA WEDLE JANA FRANCISZKA DREWNOWSKIEGO}

Jan Franciszek Drewnowski (1896-1978) był filozofem zaliczanym do środowiska szkoły lwowsko-warszawskiej, współtwórcą koła krakowskiego (obok ks. J. Salamuchy, o. J.M. Bocheńskiego, B. Sobocińskiego), oficerem wojska polskiego (uczestnikiem wojen światowych i wojny w roku 1920), pracownikiem wydawnictw technicznych. Drewnowski doktoryzował się u T. Kotarbińskiego, jego niedoścignionym mistrzem był Stanisław Leśniewski. Był jednym z pierwszych słuchaczy akademickich wykładów Leśniewskiego. Studiował na Wydziale Filozoficznym Uniwersytetu Warszawskiego: matematykę, logikę matematyczną i - jak to wtedy nazywano - filozofię naukową. Tam właśnie spotkał ks. Jana Salamuchę, który zaimponował Drewnowskiemu naukową erudycją, a intelektualną uczciwością skierował go od ateizmu ku katolickiej mistyce. W ten sposób Drewnowski wpisal się w grono intelektualnych konwertytów XX wieku, co ma znaczenie także dla jego dorobku.

$\mathrm{Na}$ problematykę, której Drewnowski poświęcił swoje zainteresowania, składają się zagadnienia stricte logiczne i metodologiczne (głownie z zakresu stosowalności logiki w nauce), filozoficzne oraz teologiczne. Główne jego dzieło - Zarys programu filozoficznego - to wyraz osobistych poglądów i pomysłów Drewnowskiego. W istocie chodziło mu o sformułowanie w nowoczesnym języku budowanym na wzór języków współczesnej logiki, całej dotychczasowej wiedzy oraz o takie dalsze rozwijanie różnych jej gałęzi, by stanowiły one integralny uniwersalny system wiedzy. Swoje dzieło pozostawił 
niedokończone. O perspektywach idei syntezy wiedzy tak pisał w artykule U podstaw nowoczesnej syntezy filozoficznej (1958): „Wtedy zdawało się nam w naszych marzeniach, że wiemy, jak realizować tę syntezę (...) Ale czy dziś kto podziela nasze przypuszczenia?”1.

Pod wpływem tego pytania zrodził się pomysł zorganizowania trzech konferencji poświęconych Drewnowskiemu jako logikowi, filozofowi oraz teologowi. Niniejsza publikacja jest częściowym zapisem pierwszej z nich, która odbyła się w Wyższym Seminarium Duchownym Diecezji Bydgoskiej w dniach 12-13 kwietnia 2018 roku pt. U podstaw syntezy wiedzy. O szlifowaniu narzędzi myślenia wedle Jana Franciszka Drewnowskiego. Patronat honorowy konferencji objął syn ś.p. Franciszka Drewnowskiego, Pan Jacek Drewnowski. Obrady podzielono na pięć sesji zatytułowanych kolejno: 1 . Teoretyczne podstawy: Cztowiek i myśliciel, 2. Elementy logiki, 3. Rozumienie nauk formalnych, 4. Praktyczne zastosowania: Ku uściślaniu filozofii, 5. Ku unowocześnionej flozofii i teologii. Zaproszeni goście wygłosili następujące referaty: Ryszard Maciołek (WSG), J.F. Drewnowskiego koncepcja znaku, ks. Marek Porwolik (UKSW), Stosunek zawierania się w systemach znakowych J.F. Drewnowskiego, Roman Murawski (UAM), J.F. Drewnowskiego flozofia matematyki i logiki, Janusz Kaczmarek (UE), O stosowaniu narzędzi i struktur formalnych w filozofii. Ontologia formalna. Ontologia topologiczna, Kordula Świętorzecka (UKSW), Jana F. Drewnowskiego nowe aksjomatyki dla Mereologii ${ }^{2}$, M. Lechniak (KUL), S. Kaminski i J.F. Drewnowski o stosowaniu logiki w fllozofi, o. Marcin Tkaczyk (KUL), Program kota krakowskiego z punktu widzenia wspótczesnej logiki, Jacek J. Jadacki (UW) Kilka uwag o tekstach Drewnowskiego (odczytała K. Świętorzecka),

1 J. F. Drewnowski, U progu nowoczesnej syntezy filozoficznej, w: Tenże, Filozofia i precyzja. Zarys programu filozoficznego i inne pisma, TN KUL, Lublin 1996, 180.

2 Uzupełniona treść wystąpienia została przedstawiona w pracy: K. Świętorzecka, M. Łyczak, Mereology with Super-Supplementation Axioms. A reconstruction of the unpublished manuscript of Jan F. Drewnowski, Logic and Logical Philosophy 2019, DOI: 10.12775/ LLP.2019.034 (w druku). 
ks. Zbigniew Wolak (UPJPII), Logiczne i metodologiczne aspekty koncepcji analogii J.F. Drewnowskiego. Wprowadzeniem do całości był cenny dwugłos wspomnieniowo-refleksyjny: Stanisława Majdańskiego (KUL), Spotkania z Filozofem. Świadectwo z odrobina refleksji, oraz Jacka Drewnowskiego, Ojciec, jakim go pamiętam.

Niniejszy tom zawiera $\mathrm{w}$ zmienionej wersji niektóre $\mathrm{z}$ tamtych referatów: M. Tkaczyk, Geneza kota krakowskiego, S. Majdański, Wokót postaci i myśli Jana Franciszka Drewnowskiego - z moich wspomnień i refleksji, M. Lechniak, Stosowanie logiki w flozofii. O dyskusji między Stanistawem Kamińskim i Janem F. Drewnowskim, R. Murawski, Jana Franciszka Drewnowskiego flozofia matematyki i logiki, J. Kaczmarek, O stosowaniu narzędzi i struktur formalnych w filozofii. Ontologia formalna. Ontologia topologiczna. Do tomu dodano też tekst U. Wybraniec-Skardowskiej pt. Logic of faith and deed. The idea and an outline of the theoretical conception, pozostający w ścisłym związku z zagadnieniami bliskimi samemu Drewnowskiemu.

Konferencja miała na celu oddać sprawiedliwość człowiekowi, który przez dyletantów nie raz był posądzany bądź o niedostateczną znajomość logiki, bądź o nadmierną pasję do niej (chociaż sam wielokrotnie podkreślał, że logika nie daje zbawczego oczyszczenia i ostrzegał przed batwochwalczq czciq symboli). Była ona też zamierzona jako zadośćuczynienie niespełnionej prośbie Drewnowskiego, skierowanej w roku 1967 listownie do Alfreda Tarskiego. Drewnowski sformułował w swoim liście spis pytań dotyczących zagadnień stosowania logiki symbolicznej, rozumienia pojęć zbioru i kategorii, stosowania autorskiej „parterowej” symboliki, filozofii procesu Whitheada i aktualnej literatury logicznej. Pytania te miały związek z zasadniczymi zrębami twórczości Drewnowskiego. W uznaniu naukowego autorytetu Tarskiego, prosił o odpowiedzi i tak motywował swoją prośbę: „Ukończyłem 70 lat i mam chore serce, tak iż raczej trzeba się "pakować«. Ponieważ zaś wśród najmłodszych moich znajomych są osoby interesujące się niektórymi moimi poglądami na stosowalność logiki symbolicznej do filozofii, chciałbym upewnić się, czy po 30 
latach coś z tych moich poglądów wytrzymuje krytykę naukową. Nie chciałbym bowiem »uwodzić« młodych ludzi na bezdroża, ani w ogóle pozostawiać w»spuściźnie «zagadnień, które są jawnie błędnie postawione"3. Adresat nigdy nie odpisał. Chcieliśmy, aby konferencyjne referaty i dyskusje zastąpiły w jakiejś części to milczenie.

Składamy serdeczne podziękowania ekonomowi Diecezji Bydgoskiej, ks. prał. Przemysławowi Książkowi, który za zgodą ks. bp. Jana Tyrawy sfinansował konferencję, rektorowi WSD DB, ks. dr. Marcinowi Puziakowi za gościnę w Seminarium, także redakcji Studia Philosophiae Christianae za opublikowanie przygotowanych do druku tekstów.

\section{Redaktorzy tomu Michat Adamczyk i Kordula Świętorzecka}

3 J. F. Drewnowski, List do Alfreda Tarskiego z maja 1967 roku, archiwum rodzinne. 